\title{
TINJAUAN KUALITAS BAKTERIOLOGIS DAN TINGKAT RISIKO PENCEMA- RAN AIR SUMUR GALI KELURAHAN SUNGAI ULIN KOTA BANJARBARU
}

\author{
Erfan Roebiakto $^{1 *}$, Yohannes Joko Supriyadi ${ }^{2}$, Gunung Setiadi ${ }^{2}$ \\ ${ }^{1}$ Jurusan Analis Kesehatan Poltekkes Kemenkes Banjarmasin \\ Jl Mistar Cokrokusumo 4a Banjarbaru, 2 Jurusan Kesehatan Lingkungan Poltekkes Kemenkes \\ Banjarmasin JI Mistar Cokrokusumo 1a Banjarbaru \\ e-mail: erpanroebiakto@yahoo.co.id
}

\begin{abstract}
Humans in meeting the needs of water should pay attention to aspects of quality and quantity. Particularly the aspect of bacteriological quality, because contaminated water can cause waterborne disease. One of the clean water facilities used by the community is the well. The community of Sungai Ulin Kota Banjarbaru uses wells for daily activities. The purpose of this research is to know the bacteriological quality and the level of risk of water pollution wells Sungai Ulin Kelurahan Kota Banjarbaru. The research type is descriptive and cross-sectional research design. The population of this study was all wells in three Rukun Tetangga (RT 19, RT 20 and RT 21) of 40 and samples of bacteriological quality of well good water. The result of the research is the characteristic of respondent from the level of education of most elementary school is 19 (47.5\%), knowledge level 21 (52,5\%), middle income category (1-3 million / month) $36(90 \%)$ and length of stay Respondents old category (> 10 years) as many as $39(78 \%)$. The conclusion of the study showed that the quality of bacteriologic (MPN Coli) of well water 3 $(7.5 \%)$ was eligible and $37(92.5 \%)$ were not eligible. The level of risk of contamination of wells to 40 wells, among others, for very high risk of 6 units (15\%), high risk of 26 units (65\%), medium risk 5 pieces (12.5\%) and low risk 3 (7.5\%). Need to do research about the relationship of good construction with bacteriological quality of good water.
\end{abstract}

Keywords: bacteriological quality, level of pollution risk, wells

Abstrak: Manusia dalam memenuhi kebutuhan akan air harus memperhatikan aspek kualitas dan kuantitas. Khususnya aspek kualitas bakteriologis, karena air yang tercemar dapat menimbulkan penyakit waterborne disease. Salah satu sarana air bersih sebagian besar yang digunakan oleh masyarakat adalah sumur gali. Masyarakat Kelurahan Sungai Ulin Kota Banjarbaru menggunakan sumur gali untuk kegiatan sehari-hari. Tujuan penelitian ini untuk mengetahui kualitas bakteriologis dan tingkat risiko pencemaran air sumur gali Kelurahan Sungai Ulin Kota Banjarbaru. Jenis penelitian adalah deskriptif dan rancangan penelitian cross sectional. Populasi penelitian ini adalah seluruh sumur gali di tiga Rukun Tetangga (RT 19, RT 20 dan RT 21) sebanyak 40 dan sampelnya kualitas bakteriologis air sumur gali. Hasil penelitian karakteristik responden dari tingkat pendidikan sebagian besar Sekolah Dasar sebesar $19(47.5 \%)$, tingkat pengetahuan baik 21 (52,5\%), tingkat penghasilan katagori sedang (13 juta/bulan) sebanyak $36(90 \%)$ dan lamanya tinggal responden katagori lama (> 10 tahun) sebanyak 39 (78\%). Kesimpulan penelitian menunjukkan kualiatas bakteriologis (MPN Coli) air sumur $3(7,5 \%)$ memenuhi syarat dan 37 (92,5\%) tidak memenuhi syarat. Tingkat risiko pemcemaran sumur gali terhadap 40 buah sumur gali antara lain untuk risiko amat tinggi sebanyak 6 buah (15\%), risiko tinggi sebanyak 26 buah (65\%), risiko sedang sebanyak 5 buah $(12,5 \%)$ dan risiko rendah sebanyak 3 buah $(7,5 \%)$. Perlu dilakukan penelitian tentang hubungan konstruksi sumur gali dengan kualitas bakteriologis air sumur.

Kata kunci: kualitas bakteriologis; tingkat risiko pencemaran; sumur gali 


\section{PENDAHULUAN}

Kehidupan manusia di dunia sangat erat hubungannya dengan air, karena air merupakan salah satu kebutuhan dasar manusia yang dapat memenuhi hajad hidup orang banyak. Didalam tubuh manusia sebagian besar terdiri air, pada tubuh orang dewasa sekitar $55-60 \%$ berat badan, anakanak sekitar $65 \%$ dan bayi sekitar $80 \%$ (Sutrisno, 1991). Manfaat sumber daya air lain untuk kepentingan rumah tangga (domestik), industri, pertanian, Perikanan dan sarana angkutan air. Dengan meningkatnya kebutuhan sumber air dan perkembangan teknologi, maka air permukaan dapat dimanfaatkan lebih luas lagi antara lain untuk sumber baku air minum dan kebutuhan industri (Asmadi, K.S., 2011)

Dalam memenuhi kebutuhan akan air, manusia selalu memperhatikan aspek kualitas dan kuantitas. Khusus untuk aspek kualitas bahwa air yang tercemar dapat menimbulkan penyakit yang dapat menyerang manusia baik secara langsung maupun tidak langsung. Penyakit yang ditularkan melalui air disebut dengan waterborne diseases atau water related diseases (Lud Waluyo,2005). Berdasarkan Permenkes RI Nomor : 416/Menkes/Per/ IX/1990, bahwa yang dimksud dengan air bersih adalah air yang digunakan untuk keperluan sehari-hari yang kualitasnya memenuhi syarat kesehatan baik fisik, kimia dan bakteriologis dan dapat diminum apabila telah dimasak (Depkes, 1990)

Salah satu sarana air bersih yang sebagian besar masih dimanfaatkan oleh masyarakat Indonesia adalah air sumur gali. Berdasarkan hasil Riset Kesehatan Dasar tahun 2014 menunjukkan bahwa proporsi rumah tangga berdasarkan jenis sumber air minum di Indonesia terbesar adalah sumur gali $(22,5 \%)$ air isi ulang (21\%) dan air sumur bor/ pompa (12,8\%) (Kemenkes, 2014). Hal ini mungkin disebabkan karena sumur gali mudah dalam pembuatan dan dapat dibuat oleh masyarakat sendri dengan peralatan yang sederhana dan biaya yang cukup murah. Namun sumur gali mempunyai tingkat risiko pencemaran sangat tinggi karena mudah terkontaminasi melalui rembesan, umumnya berasal dari tempat pembuangan kotoran manusia, pembuangan kotorran hewan juga berasal dari limbah sumur itu sendiri baik lantai maupun saluran air limbahnya yang tidak kedap air.

Keluruhan Sungai Ulin Kota Banjarbaru masyarakatnya sebagian besar menggunakan sumur gali unruk kegiatan sehari baik untuk memasak, minum, mencuci dan mandi, meskipun terdapat beberapa komplek perumahan rakyak (KPR BTN) yang sudah dilayani air bersih dari PDAM. Dari data yang diperoleh dari Kelurahan Sungai Ulin jumlah penduduk pada tahun 2014 sebanyak 9.350 jiwa dan terbagi menjadi 42 Rukun Tetangga. Data penyakit tahun 2014 di Puskesmas Sungai Ulin menggambarkan bahwa penyakit diare masuk dalam sepuluh besar penyakit yang ditularkan melalui air (water Borne Disease). Dan dari hasil pengamatan pegamatan sumur gali yang digunakan tidak memenuhi syarat kesehatan dari segi konstruksi baik lantai, bibir sumur,dinding sumur, saluran air limbah dan jarak dengan pembuangan kotoran. Hal ini dapat meninbulkan risiko pencemaran terhadap sumur gali. Berdasarkan fakta-fakta diatas maka perlu dilakukan penelitian tentang tinjauan kualitas bakteriologis dan tingkat risiko air sumur gali di Kelurahan Sungai Ulin Kota Banjarbaru.

\section{BAHAN DAN METODE}

Jenis penelitian ini merupakan penelitian diskriptif dengan rancangan crsos sectional dimana faktor sebab dan akibat diambil secara bersamaan dengan waktu yang sama (Soekijo, 2010). Populasi penelitian ini adalah sumur gali di Kelurahan Sungai Ulin (RT 19, RT 20 dan RT 21) sebanyak 40 sedangkan sampelnya adalah kualitas bakteriologis air sumur gali dan cara pengambilannya total sampel.

Variabel penelitian meliputi karakteristik penduduk (tingkat pendidikan, pengetahuan, penghasilan); gambaran konstruksi sumur, kualitas bakteriologis (MPN Coli); tingkat risiko pencemaran air sumur gali. Tempat penelitian di kelurahan Sungai Ulin RT 19, RT 20 dan RT 21. Waktu penelitian dilakukan selama 6 bulan. Cara pengmbilan data primer menggunakan kuisioner, lembar observasi, formulir inspeksi sanitasi sumur gali dan peralatan dan bahan laboratorium untuk pengambilan sampel air sumur. Dan pemeriksaan kualitas bakteriologis air sumur gali di laboratorium PDAM Intan. Data yang diperoleh dari hasil penelitian diaolah dan disajikan dalam bentuk tabel kemuadian dianalisa secara deskriptif dan hasil pemeriksaan kualitas bakteriologis air sumur gali dibandingkan dengan standart menurut Permenkes Nomor 416/Menkes/ PER/IX/1990 tentang Persyaratan dan Pengawasan Kualitas Air Bersih. 
HASIL DAN PEMBAHASAN

Karakteristik Responden

Tabel 1. Distribusi Frekuensi Karakteristik Responden Kelurahan Sungai Ulin Kota Banjarbaru

\begin{tabular}{clrr}
\hline Variabel & \multicolumn{1}{c}{ Katagori } & Jumlah & $\begin{array}{r}\text { Persentase } \\
(\%)\end{array}$ \\
\hline Pendidikan & SD & 19 & 47,5 \\
& SMP & 11 & 27,5 \\
& SMA & 10 & 25 \\
& Tinggi (> 3 juta/bulan) & 1 & 2,5 \\
Lama Tinggal & 29 & 72,5 \\
& Sedang (1-3 juta/bulan) & 10 & 25 \\
& Rendah (<1 juta/bulan) & 29 & 72,5 \\
& Lama (> 10 tahun) & 9 & 22,5 \\
Pekerjaan & Cukup lama (5 - 10 & 2 & 2,5 \\
& Tahun) & & \\
& Baru (<5 tahun) & 4 & 10 \\
& Purnawirawan & 30 & 75 \\
& Swasta & 4 & 10 \\
& Sopir & 2 & 5 \\
Pengetahuan & Dagang & 21 & 52,5 \\
& Baik & 16 & 40 \\
& Sedang & 3 & 7,5 \\
\hline
\end{tabular}

Berdasarkan tabel diatas, hasil penelitian terhadap karakteristik responden untuk tingkat pendidikan katagori SD sederjat sebanyak 19 orang $(47,5 \%)$, tingkat penghasilan per bulan katagori sedang (1-3 juta) sebanyak 29 orang $(72,5 \%)$, lama tinggal responden katagori lama ( > 10 tahun) sebanyak 29 orang (72,5\%) dan pekerjaan responden katagori swasta sebanyak 30 orang $(75 \%)$, serta tingkat pengetahuan responden katagori baik sebanyak 21 orang $(52,5 \%)$.

\section{Konnstruksi Sumur Gali}

Tabel 2 :Distribusi Frekuensi Konstruksi Sumur Gali Responden di Kelurahan Sungai Ulin Kota Banjarbaru

\begin{tabular}{llrr}
\hline \multicolumn{1}{c}{ Variabel } & \multicolumn{1}{c}{ Katagori } & Jumlah & $\begin{array}{r}\text { Persentase } \\
(\%)\end{array}$ \\
\hline Bibir Sumur Gali & MS ( $\geq 80$ Meter) & 18 & 45 \\
& TMS (<80 Meter) & 22 & 55 \\
Dindng Sumur Gali & MS ( $\geq 3$ meter) & 7 & 17,5 \\
& TMS (<3 meter) & 33 & 82,5 \\
Lantai Sumur Gali & MS ( $\geq 1$ meter) & 7 & 17,5 \\
Saluran Pembuangan & TMS (<1 meter) & 33 & 82,5 \\
Air Limbah ( & TMS (<11 meter) & 3 & 7,5 \\
Jarak Sumur Gali & MS ( $\geq 11$ meter) & 37 & 92,5 \\
dengan Sumber & TMS (<11 meter) & 17 & 42,5 \\
Pencemar & & 23 & 57,5 \\
\hline
\end{tabular}

Dari tabel tersebut diatas, hasil penelitian menggambarkan konstruksi sumur gali dengan bibir sumur yang memenuhi syarat hanya 18 buah (45\%). Hasil observasi dijumpai bahwa sumur gali penduduk sudah memiliki bibir sumur setinggi $80 \mathrm{~cm}$ namun masih terdapat lubang atau retak pada dinding tersebut. Sedangkan yang tidak memenuhi syarat 22 buah (55\%). Menurut Candra
(2007), bahwa sumur yang sehat minimal harus memiliki bibir sumurgali yang dibuat dari tembok yang kedap air setinggi $80 \mathrm{~cm}$ untuk mencegah pengotoran dari air permukaan yang masuk kedalam air sumur serta menjaga keselamatan pemakai. Menurut Asmadi (2011), menyebutkan bahwa penyakii yang dapat ditularkan melalui air diakibatkan karena masuknya tinja hewan maupun manusia ke dalam air. Pencemaran tinja memungkin organisme penyebab penyakit akan tersebar melalui penyediaan air bersi dan menyebabkan penyebaran penyakit secara luas, apabila orang orang meminum air tersebut seperti tifoid, kolera dan hepatitis infectiosa

Dinding sumur responden yang tidak memenuhi syarat sebanyak 33 buah $(82,5 \%)$. Kondisi sumur gali penduduk yang tidak mempunyai dinding kedap air sudah semakin melebar karena terkikis oleh rembesan air. Maka untuk mencegah semakin melebarnya dinding sumur sebagian penduduk memasang balok-balok kayu pada dinding sumur. Menurut Udin Jabo, dkk (1991), bahwa pola pencemaran bakteri dan kimia terhadap air dan tanah dengan jarak yang ditempuh tergantung beberapa faktor, salah satu faktor terpenting adalah porositas tanah. Jenis tanah sumur gali responden campuran tanah dan lempung serta bebatuan. Keadaan diding sumur yang tidak memenuhi syarat yaitu tidak kedap air kurang dari 3 meter dapat menyebabkan terjadinya perembesan pencemaran yang berasal dari diding yang tidak kedap air sehingga menyebabkan bakteri yang ada pada lapisan akan ikut masuk kedalam sumur Lantai sumur gali responden yang tidak memenuhi syarat sebanyak 33 buah $(82.5 \%)$. Sebagian besar responden sudah membuat lantai $\geq 1$ meter namun hanya hanya sebagian dari sisi sumur gali yang mengarah/ menghadap rumah sebagian tidak membuat lantai kedadap air, padahal aktivitas penduduk dilakukan sekitar sumur. Kondisi lantai sumur yang tidak memenuhi syarat dapat menyebabkan terjadinya pencemaran yang ditimbulkan oleh bakteri terhadap air yang ada di dalam tanah melebar sampai \pm 2 meter searah dengan aliran air

Saluran Pembuangan Air Limbah (SPAL) pada sumur gali yang tidak memenuhi syarat sebanyak 37 buah (92,5\%). 
Saluran air pembuangan air limbah ini digunakan untuk mengalirkan air yang telah digunakan agar tidak menimbulkan pencemaran gangguan pada lantai sumur dan sebagian penduduk mengalirkan ketempat terbuka tidak jauh dari sumur gali. Menurut Sugiarto (1987), bahwa mekanisme pencemaran yang ditimbulkan oleh bakteri terhadap air yang ada dalam tanah melebar sampai 2 meter dan pada jarak 5 meter dari sumber pencemar akan menyempit hingga jarak 11 meter searah dengan aliran tanah. Dan pencemaran disebabkan kandungan bahan kimia dapat mencapai jarak sejauh 95 meter mengikuti bentuk yang hampir sama dengan pencemaran bakteri.

Jarak sumur gali responden dengan sumber pencemar yang tidak memenuhi syarat kurang dari 11 meter sebanyak 23 buah $(57,5 \%)$. Sumber pencemaran berasal dari jamban (kakus), tumpukan sampahrumah tangga, kandang ternak. Jarak yang kurang dari 11 menter antara sumur gali dengan sumber pencemaran dapat menyebabkan air sumur gali bisa terkontaminasi dengan kotoran tinja manusia yang mengandung bakteri patogen seperti Escherichia coli, yaitu bakteri yang dapat menyebabkan penyakit bawaan air (water borne disesase) yakni penyakit diare (Lud Waluyo, 2005). Mekanisme pencemaran yang ditimbulkan bakteri terhadap air dalam tanah melebar sampai kurang 2 meter pada jarak 5 meter dari sumber pencemar kemudian menyempit hingga jarak 11 meter searah dengan aliran air tanah.

\section{Tingkat Risiko Pemcemaran Air Sumur Gali}

Tabel 3. Distribusi Trekuensi Tingkat Risiko Pemcemaran Sumur Gali Responden di Kelurahan Sungai Ulin Kota Banjarbaru

\begin{tabular}{cccc}
\hline No & $\begin{array}{c}\text { Tingkat Risiko } \\
\text { Pencemaran Sumur Gali }\end{array}$ & Frekuensi & $\begin{array}{c}\text { Persentase } \\
(\%)\end{array}$ \\
\hline 1 & Amat tinggi & 6 & 15 \\
2 & Tinggi & 26 & 65 \\
3. & Sedang & 5 & 12,5 \\
4 & Rendah & 3 & 7.5 \\
5 & Jumlah & 40 & 100 \\
\hline
\end{tabular}

Sedangkan untuk diagnnosa tingkat risiko pencemaran sumur gali responden hasil diagnosa tingkat risiko pencemaran sumur gali responden yang paling besar adalah lantai sumur yang lantai sumur yang retak-retak yaitu $36(90 \%)$ dapat dlihat pada tabel berikut:
Tabel 4. Distribusi frekuensi Diagnosa Tingkat Risiko Pencemaran Sumur Gali Responden di Kelurahan Sungai Ulin Kota Banjarbaru

\begin{tabular}{|c|c|c|c|c|c|}
\hline \multirow[t]{2}{*}{ No } & \multirow[t]{2}{*}{ Variabel } & \multicolumn{4}{|c|}{$\begin{array}{c}\text { Tingkat Risiko } \\
\text { Pencemaran Sumur Gal }\end{array}$} \\
\hline & & $\mathrm{Ya}$ & $\%$ & Tdk & $\%$ \\
\hline 1 & Jarak jamban < 10 m dari sumur gali & 15 & 37,5 & 25 & 62,5 \\
\hline 2 & $\begin{array}{l}\text { Sumber pencemar lain radius } 10 \mathrm{~m} \text { dari } \\
\text { SGL }\end{array}$ & 25 & 62,5 & 15 & 37,5 \\
\hline 3 & Genangan air $\leq 2 \mathrm{~m}$ dari sumur gali & 25 & 62,5 & 15 & 37,5 \\
\hline 4 & Lantai semen sumur gali radius $\leq 1 \mathrm{~m}$ & 35 & 87,5 & 5 & 12,5 \\
\hline 5 & SPAL kondisi rusak atau tidak adak & 34 & 85 & 6 & 15 \\
\hline 6 & Genangan air diatas lantai sumur gali & 28 & 70 & 12 & 30 \\
\hline 7 & Keretakan lantai sumur gali & 36 & 90 & 4 & 10 \\
\hline 8 & $\begin{array}{l}\text { Ember dan tali timba diletakan } \\
\text { sembarangan }\end{array}$ & 10 & 25 & 30 & 75 \\
\hline 9 & Bibir sumur gali tidak sempurna & 22 & 55 & 18 & 45 \\
\hline 10 & $\begin{array}{l}\text { Dinding semen SGL sedalam } 3 \mathrm{~m} \\
\text { diplester }\end{array}$ & 35 & 87,5 & 5 & 12,5 \\
\hline
\end{tabular}

\section{Pemeriksaan Kualitas Bakteriologis (MPN Coli) Air Sumur Gali}

Tabel 5.Distribusi Frekuensi Hasil Pemeriksaan Kualitas Bakteriologis Air Sumur Responden di Kelurahan Sungai Ulin Kota Banjarbaru

\begin{tabular}{clcc}
\hline No & $\begin{array}{c}\text { Kualitas Bakteriologis (MPN } \\
\text { Coli) Sumur Gali }\end{array}$ & Frekuensi & $\begin{array}{c}\text { Persentase } \\
(\%)\end{array}$ \\
\hline 1 & $\begin{array}{l}\text { Memenuhi Syarat ( } \leq 50 / 100 \\
\text { Sampel Air) }\end{array}$ & 3 & 7,5 \\
2 & $\begin{array}{l}\text { Tidak Memenuhi Syarat }(\leq \\
50 / 100 \text { Sampel Air) } \\
\text { Jumlah }\end{array}$ & 37 & 92,5 \\
& \multicolumn{1}{c}{40} & 100 \\
\hline
\end{tabular}

Berdasarkan tabel diatas, kandungan bakteri Coliform (MPN Coli) melebihi standart yang telah ditentukan berdasarkan Permenkes Nomor 416/Menkes/Per/IX/1990 tentang SyaratSyarat dan Pengawasan Kualitas Air bersih yaitu kadar maksimum yang diperbolehkan $50 / 100 \mathrm{ml}$ sampel air bukan perpiaan. Hal ini berarti air sumur gali telah tercemar oleh kotoran manusia atau hewan yang dapat menyebabkan penyakit pada saluran pencernaan (diare).

Hubungan Tingkat Risiko Pencemaran Sumur Gali dengan Kualitas Bakteriologis (MPN Coli)

Tabel 6. Distribusi Frekuensi Hubungan Tingkat Risiko Pencemaran Sumur Gali dengan Kulitas Bakteriologis (MPN Coli) Sumur Gali Responden di Kelurahan Sungai Ulin Kota Banjarbaru

\begin{tabular}{ccccccc}
\hline \multirow{2}{*}{$\begin{array}{c}\text { Tingkat Risiko } \\
\text { Pencemaran Sumur Gali }\end{array}$} & \multicolumn{9}{c}{$\begin{array}{c}\text { Kualitas Bakteriologis } \\
\text { (MPN Coli) }\end{array}$} & $\begin{array}{c}\text { Sumur Gali } \\
\text { MS }\end{array}$ & \multicolumn{2}{c}{ TDK MS } \\
\cline { 2 - 7 } & $\sum$ & $\%$ & $\sum$ & $\%$ & $\sum$ & $\%$ \\
\hline Amat Tinggi & 1 & 2,5 & 5 & 12,5 & 6 & 15 \\
Tinggi & 1 & 2,5 & 25 & 62,5 & 26 & 65 \\
Sedang & 1 & 2,5 & 4 & 10 & 5 & 12.5 \\
Rendah & - & - & 3 & 7,5 & 3 & 7,5 \\
Jumlah & 3 & 7,5 & 37 & 92,5 & 40 & 100 \\
\hline
\end{tabular}


Berdasarkan tabel tersebut diatas, bahwa tingkat risiko pencemaran sumur gali terhadap kualitas bakteriologis (MPN Coli) yaitu tingkat risiko tinggi 25 buah $(62,5 \%)$ tidak memenuhi persyaratan bakteriologis (MPN Coli), hal ini disebabkan oleh kontruksi sumur gali yang tidak memenhui syarat kesehatan seperti jarak sumur gali kurang dari 11 meter dari sumber pencemar sebanyak 15 buah $(37,5 \%)$. Selain itu juga dipengaruhi oleh jarak dengan sumber pencemaran mempunyai risiko amat tinggi 25 buah $(62,5 \%)$, sehingga dapat menyebabkan air sumur gali terkontaminasi oleh kotoran manusia (tinja) yang mengandung bakteri patogen yaitu Escherichia coli (E.coli) yang dapat menyebabkan penyakit bawaan air (water borne disease). Maka air sumur gali sebelum digunakan untuk kegiatan sehari-hari misalnya untuk minum harus dimasak lebih dahulu.

\section{KESIMPULAN}

Penelitian menunjukkan kualiatas bakteriologis (MPN Coli) air sumur $3(7,5 \%)$ memenuhi syarat dan $37(92,5 \%)$ tidak memenuhi syarat. Tingkat risiko pemcemaran sumur gali terhadap 40 buah sumur gali antara lain untuk risiko amat tinggi sebanyak 6 buah (15\%), risiko tinggi sebanyak 26 buah $(65 \%)$, risiko sedang sebanyak 5 buah $(12,5 \%)$ dan risiko rendah sebanyak 3 buah $(7,5 \%)$.

\section{SARAN}

Penelitian selanjutnya dapat dilakukan tentang hubungan konstruksi sumur gali dengan kualitas bakteriologis air sumur.

\section{DAFTAR PUSTAKA}

Asmadi, K.S. (2011). Teknologi Pengolahan Air Minum. Yogyakarta.

Candra, B. (2007). Pengantar Kesehatan Lingkungan. Jakarta: EGC.

DepKes RI. (1990). Permenkes No. 416 tahun 1990 Tentang Syarat-syarat dan Pengawasan Kualitas Bersih.

Kesehatan Kementerian. (2014). Riskesdas Badan Penelitian dan Pengembangan Kesehatan Departemen Kesehatan Republik Indonesia. Jakarta.

Lud, W. (2005). Mikrobiologi Lingkungan. Universitas Malang.

Notoatmodjo, S. (2010). Metodologi Penelitian Kesehatan. Jakarta: Rineka Cipta.

Puskesmas Sungai Ulin. (2014). Laporan Profil Puskesmas tentang Data Sepuluh Penyakit terbanyak.

Soegiharto. (1987). Dasar-Dasar Pengelolaan Air Limbah. Jakarta: Universitas Indone- sia.

Sutrisno, T. (1991). Teknologi Penyediaan Air Bersih. Jakarta: Rineka Cipta.

Udin, J. (1991). Pedoman Bidang Studi Pembuangan Tinja dan Air Limbah pada Institusi Pendidikan Sanitasi/Kesehatan Lingkungan. Jakarta: Departemen Kesehatan Pusat Pendidikan Tenaga Kesehatan. 